\title{
Integrating habitat restoration and fisheries management: A small-scale case-study to support EEL conservation at the global scale
}

\author{
E. Ciccotti ${ }^{(1)}$, C. Leone ${ }^{(1) \star}$, D. Bevacqua ${ }^{(2)}$, G. De Leo ${ }^{(3),(4)}$, L. Tancioni ${ }^{(1)}$, \\ F. Capoccioni ${ }^{(1)}$
}

Received September 19, 2012

Revised October 11, 2012

Accepted December 11, 2012

Key-words: river restoration, eel conservation, Anguilla anguilla, Mediterranean, fishery management

\section{ABSTRACT}

The aim of this work was to develop a methodological framework for the management of local eel stocks that integrates habitat restoration with optimal fishery management. The Bolsena lake (Viterbo, Italy) and its emissary, the river Marta, were taken as a reference system. The river flows in the Mediterranean sea but its course is fragmented by a number of dams built in the past century preventing eel migration from and to the sea. Eel fishery in the Bolsena lake is thus sustained by periodic stocking of glass eels caught at the Marta river estuary.

A detailed demographic model was applied to simulate fishery yields and potential spawner escapement under different recruitment and management scenarios. It was estimated that the high exploitation rates occurring in the nineties reduced the potential spawner escapement from the Bolsena lake to less than $1 \mathrm{t}$; under current harvesting rates, the potential spawner escapement is estimated in about $12 \mathrm{t}$ while in pristine conditions (i.e. high recruitment and no fishing) estimated spawner escapement is about $21 \mathrm{t}$. This analysis thus showed that current fishery management would comply with the $40 \%$ spawner escapement requirement of the EU regulation 1100/2007 if the connections between the Bolsena lake emissary and the sea were fully re-established. This confirms the opportunity of an integrated approach to management at the catchment area level scale for eel populations, that shall hopefully contribute to the conservation of the global stock.

\section{RÉSUMÉ}

Intégrer la restauration de l'habitat et la gestion des pêcheries : un cas d'étude pour la conservation de l'anguille a l'échelle globale

Mots-clés : restauration de rivières,
L'objectif de ce travail était la mise en place d'un cadre méthodologique pour la gestion des sous-populations locales d'anguille basée sur l'intégration de la restauration de l'habitat et de la gestion optimale des pêcheries. Le système de référence est le lac de Bolsena (Viterbo, Italie) avec son émissaire, la rivière Marta.

(1) Dipartimento di Biologia - Università di Roma "Tor Vergata, Via della Ricerca Scientifica s.n.c., 00133 Roma, Italia

(2) INRA, UR1115 PSH, Avignon, France

(3) Dipartimento di Scienze Ambientali - Università di Parma, Viale G.P. Usberti 11/A, 43100 Parma, Italia

(4) Holpkins Marine Station and Woods Institute for the Environment, Stanford University, California 15, USA

* Corresponding author: chiara.leone@uniroma2.it 
conservation, anguille, Anguilla anguilla, Méditerranée, gestion des pêcheries
La rivière se jette dans la mer Méditerranée mais son cours est fragmenté par un certain nombre de barrages construits au siècle dernier. La pêche à l'anguille dans le lac de Bolsena est donc soutenue avec repeuplements effectués avec des civelles capturés à l'embouchure du fleuve Marta. Un modèle démographique détaillé a été utilisé pour simuler les rendements de la pêche et la production d'anguilles argentées, sous différents scénarios de recrutement et de gestion de la pêcherie.

II a été estimé que les taux d'exploitation élevés dans les années 90 ont réduit l'échappement potentiel du lac de Bolsena à moins de $1 \mathrm{t}$; aux niveaux d'exploitation actuels, l'échappement potentiel est estimée à environ $12 \mathrm{t}$, tandis que l'échappement correspondant au niveau original (haut recrutement et aucune pêche) est estimé à environ $21 \mathrm{t}$.

Cette analyse ainsi démontre que la gestion des pêches actuelle serait conforme au niveau d'échappement minimal requis par la réglementation européenne $1100 / 2007$ si la connexion entre le lac et la mer était définitivement rétablie. Cela confirme l'opportunité d'une approche intégrée à l'échelle du bassin versant pour l'anguille, qui pourra contribuer à la conservation du stock à l'échelle globale.

\section{INTRODUCTION}

Over the past 100 years, inland water habitats have suffered most among all ecosystems as result of a wide variety of uses of aquatic systems, that all entail a legacy for impacting on the environment (Cowx, 2002). Impacts range from pollution, introduction of invasive species, flow regulation or impoundments, overexploitation can have all a dramatic, direct impact on the integrity of freshwater ecosystems. Other environmental pressures, such as those driven by land use change and climate change (Allan 2004) or by the development of tourist activities (Hadwen et al., 2003) may also have consequences for the aquatic ecosystems that are only apparently less important (Maitland, 1995; Cowx and Welcomme, 1998; Poff et al., 2001; Tancioni et al., 2006).

Altogether these anthropogenic pressures threaten the conservation of fish population and the sustainability of their fisheries in continental waters. Several conservation strategies have been developed to protect threatened fish populations. Key actions rely on habitat restoration, stock enhancement, fishery management and establishment of protected areas, the latter being scarcely feasible in inland waters because the limited spatial extention of these habitats prevent the exclusion of other human activities in the same areas. Concern has been raised also about the contribution of fishery management to effective conservation (Cowx, 2002; Collares-Pereira and Cowx, 2004), because of the need to trade off between multiple conflicting uses of the same environment and/or natural resources. The conservation of fish biodiversity, in fact, usually have a marginal importance from an economic and social perspective with respect to more profitable human activities.

A possible exception to this general picture might be the case of the catadromous European eel, Anguilla anguilla, an economically and culturally important fishery resource throughout Europe (Feunteun, 2002; Ringuet et al., 2002) and a species for which a urgent conservation issue exists. Eel is exploited by capture fisheries in a wide range of habitats, such as estuaries, rivers and lakes, targeted at all life stages, and is also farmed throughout Europe, an activity based on the rearing of wild-caught juvenile glass eels and elvers.

Eel larvae, the leptocephali, cross the Atlantic Ocean from the spawning area in the Sargasso Sea to European and North African coasts. After metamorphosis to glass eels and then to elvers, eel complete migration into continental waters (coastal lagoon, rivers, lakes, ponds and canals), where they grow into yellow eels. After a feeding period of several years, they make the final transition into silver eels that migrate back to the Sargasso Sea, where they reproduce and then die (Tesch, 2003). The panmictic eel population (Dannewitz et al., 2005; 
Pujolar et al., 2009; Als et al., 2011) experienced a continent-wide decline in recruitment observed in the last few decades and a consequent contraction in adult eel capture fisheries (Moriarty and Dekker, 1997; ICES, 2004, 2005; Dekker, 2008).

A number of potential causes of eel decline have been considered ranging from climate change and its influence on oceanic migration to anthropogenic factors such as overexploitation, pollution, parasite infection, obstacles to migration, turbine mortality and habitat loss (Feunteun, 2002; ICES, 2007; Dekker, 2008).

At the end of a long political and scientific process (Bevacqua et al., 2009a) in September 2007 a Council Regulation (EC 1100/2007) established a framework for the recovery of the European eel stock. In 2007, the European eel was added to the CITES Annex II in order to control its international trade, and in 2008 it was listed as critically endangered in the IUCN Red List of Threatened Species (IUCN, 2010).

The recovery of a fish stock with a such a complex life cycle presents major challenges, including the fact that restoration measures cannot target directly oceanic life stages and consequently protective measures are restricted to the continental phases. In conservation terms, the main objective of eel management actions is to allow an adequate escapement of silver eel biomass, silver eel being the key stage to be controlled if a positive effect on recruitment, i.e. glass eels ascending continental waters, is to be expected after management interventions. Accordingly, the EU Regulation 1100/2007 requires all member states to implement a variety of recovery measures - including habitat restoration, removal of dams and other migration obstacles and/or construction of fish passes and reduction of fishing mortality - aimed at allowing at least $40 \%$ of the potential spawning stock in pristine conditions to escape back to the sea for reproduction.

Against this background, the present work aims at setting up methodological framework for the management of eel local stocks at the catchment scale and for the evaluation of the biomass of escaping mature eels. The studied system is the Bolsena lake with its emissary, the river Marta. This system is representative of many lentic systems in central Italy, where a number of lakes of volcanic origin represent freshwater habitats suitable for eel. Bolsena lake exhibits a high trophic level and a good environmental quality (Barbanti et al., 1971; Orban et al., 2007; Pujolar et al., 2012) and the eel local stock, customarily sustained by stockings that have a long-standing tradition in Italy, supports a fishery since the 19th century.

Combining restoration of natural longitudinal connectivity with a sustainable management of fisheries, and assessing escapement based on a modelling approach, this study aims at defining basic elements for the implementation of a specific management strategy tailored to local conditions (Dekker, 2009). Indeed it is widely agreed that case-adapted management options represent at present the way ahead for eel, with the ultimate goal to protect the species and to generally contribute to delay biodiversity loss.

\section{MATERIALS AND METHODS}

\section{> STUDY SITE}

The Marta-Bolsena hydrological system consists of a lake of volcanic origin connected to the sea through a tributary river. The Bolsena lake (Figure 1), the largest in central Italy covering a surface of $114 \mathrm{~km}^{2}$, is circular in shape, has an average depth of $81 \mathrm{~m}$ (maximum depth $151 \mathrm{~m}$ ), a volume of $9.2 \mathrm{~km}^{3}$ and drains a catchment area of $159 \mathrm{~km}^{2}$. Annual water supply to the lake is less than $1 \%$ of the lake volume and is due to some creeks on the northern side and to a greater extent to rain. The Bolsena watershed (Figure 1) is directly connected to the river Marta, emissary from the lake, that flows directly into the Tyrrhenian Sea, with a total drainage basin of $1091 \mathrm{~km}^{2}$ (Fantucci, 2007). The Marta river, $49 \mathrm{~km}$ long, is an emissary of the lake with water exchanges between lake and river being regulated by a sluice gate. The river is also supplied downstream by a number of tributaries (Figure 1A). The river course is mostly laminar with few rapids and a natural waterfall (cascata della Salombrona) about $10 \mathrm{~m}$ in height, $11 \mathrm{~km}$ downstream the lake outlet. The longitudinal profile of the Marta river 


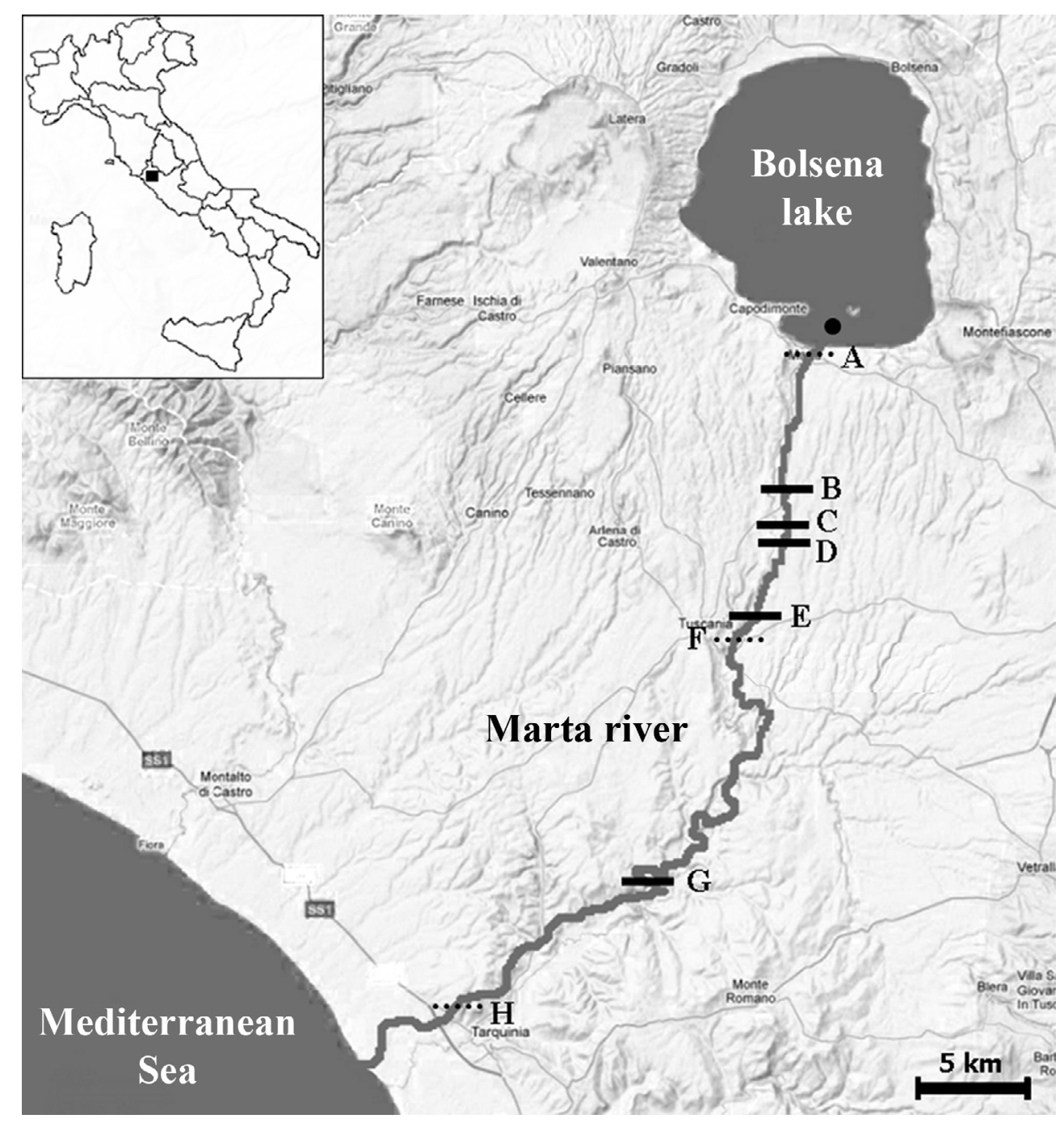

Figure 1

Catchment area of the Bolsena lake-Marta river system. Bars and capital letters $(A-H)$ represent the discontinuities along the river course, where interventions have been implemented. Marta sluice $(A)$, San Savino III (B), San Savino II (C), San Savino I (D), Fioritella (E), Tuscania paper mill (F), Guado della Spina (G), Isola Ecologica (H). Asterisk (") is the Salombrona waterfall, the black circle (•) in the lake is the fishing area where the samplings by fyke nets were carried out.

was heavily modified by the construction of four power stations: S. Savino III (Figure 1B), S. Savino II (Figure 1C), S. Savino I (Figure 1D) and Fioritella (Figure 1E), by the Tuscania paper mill intake (Figure 1F) and by some small dams for agricultural use. Between 2006 and 2007, several interventions (by-pass channels and fish passes) were implemented by the Province of Viterbo, to restore both the physical and the hydraulic continuity on the river course, with the aim of compensating impacts of habitat fragmentation on fish populations (AGEI, 2008). The effectiveness of these interventions is still to be proven, and a monitoring program is currently in progress. Anyway, at present both glass eel upstream colonization and silver eel downstream migration are still impaired by the presence of the waterfall as well as by the reduced efficiency of fish passes.

Despite the absence of natural migration, commercial eel fisheries have been operated for more than a century both in the Marta river and in the Bolsena lake. A small glass eel fishery is located in the river Marta estuary, where a single licensed fisher harvest glass eels by using fyke nets during the glass eel ascent season, usually in November-February. Glass 
eel yield fluctuates from year to year depending mostly on the river hydrological regime and environmental variability, but has remained fairly stable between the end of the 1990's and 2010, despite the progressive drop in recruitment observed everywhere (ICES, 2009). Glass eel catches are usually sold for aquaculture and restocking purposes, and a quota is usually employed to stock the Bolsena lake.

There are 65 fishermen commercially exploiting several fish species in the lake. A characterization of the eel fishery was carried out in 2007-2010 by detailed interviews to the fishers to assess fishing effort, catch by stage, and fishing yields from 1996 to 2006 were obtained (ARSIAL, 2009). Restocking data from the '90s up to 2008 were obtained by the Province of Viterbo. Data from the eel fishery characterization and restocking data were used for the model estimates of escapement.

\section{> SAMPLING PROCEDURES}

Yellow and silver eels were sampled in Bolsena lake between May and October 2009, during the eel fishing season. Sampling was carried out with the fishermen by fyke netting in the southern area of the lake. Fyke nets consisted of four chambers (diameter from $2 \mathrm{~m}$ to $30 \mathrm{~cm}$ ), $16 \mathrm{~mm}$ codend mesh size, two $10 \mathrm{~m}$ long lateral wings (mesh size $18 \mathrm{~mm}$ ) and a $25 \mathrm{~m}$ long leader central net (called "longarina", mesh size $20 \mathrm{~mm}$ ). Samples were randomly collected among catches.

\section{> SAMPLE EXAMINATION}

A total of 177 eels were sacrificed, measured for total length $(L)$, weight, and three morphometric parameters (i.e. pectoral fin length, vertical and horizontal eye diameters), aged through otolith reading, and visually inspected to determine sex and maturation stage. Otoliths were extracted, embedded in epoxyn resin and stained with $3 \%$ toluidine blue following grinding of the convex side (grinding and polishing method; ICES, 2009). Fish age was determined by reading annual otolith rings (annuli) from the first growth check (age 1+) outside the so called "zero band". This band is commonly assumed as the beginning of continental growth in eel (Moriarty, 1983; Poole et al., 2004; ICES, 2009). Sex was assessed macroscopically whenever possible, or by histological examination of gonads (Colombo and Grandi, 1996). Maturation stage was determined combining gonad development, Pankhurst's (1982) ocular index (OI) which reflects changes in eye diameter during metamorphosis to the silver stage (Acou et al., 2009) and Durif's silvering index (Durif et al., 2005).

\section{> DATA ANALYSIS AND SIMULATION MODEL}

Mean annual growth [mm yr${ }^{-1}$ ] was calculated for both females and males according to the formula used by Lin et al. (2009) as described in Appendix A. Growth trajectories were modeled with a von Bertalanffy growth curve for females and a linear growth curve for males, estimated on the available data (Appendix A).

The simulation model describing eel demography in the continental phase (i.e. from glass eel stocking to silver eel escapement) was developed by Bevacqua et al. (2007) and explicitly accounted for key aspects of its life-history, such as high natural mortality in the acclimation phase and lower natural mortality in the following phase (Dekker, 2000; Bevacqua et al., 2011), density-dependent mortality from the glass to the elver stage, body size and fishing effort dependent fishing mortality (Bevacqua et al., 2009b), sex specific body growth (Melià et al., 2006a), size- and sex-specific maturation rates, as females reach sexual maturity at a considerably larger size (Bevacqua et al., 2006) (detailed explanation in Appendix A). Model parameters were derived from the available data and literature. Annual fishing effort is expressed as net per days (i.e. average number of nets that are in use per day). Eel catchability $q$, a parameter that multiplied by fishing effort provides the overall fishing mortality, was 
Table I

Mean, standard deviation and range of biometric measures of yellow and silver eels of the Bolsena Lake samples.

\begin{tabular}{|c|c|c|c|c|}
\hline \multicolumn{2}{|r|}{ BOLSENA SAMPLE } & $N$ & Mean \pm SD $(\mathrm{mm})$ & Range \\
\hline \multirow{5}{*}{$\frac{3}{3}$} & TL (Total length) & \multirow{5}{*}{106} & $458.5 \pm 114.4$ & $245.0-800.0$ \\
\hline & W (Weight) & & $210.1 \pm 201.4$ & $19.6-1070.7$ \\
\hline & Ov (Vertical Eye Diameter) & & $4.6 \pm 1.2$ & $2.2-8.0$ \\
\hline & Oh (Orizontal Eye Diameter) & & $5.1 \pm 1.3$ & $2.6-8.9$ \\
\hline & Lpf (Pectoral fin length) & & $19.2 \pm 6.3$ & $5.1-39.7$ \\
\hline \multirow{5}{*}{$\frac{\text { 妥 }}{\text { 户 }}$} & $\overline{T L}$ (Total length) & \multirow{5}{*}{71} & $548.2 \pm 150.0$ & $345.0-920.0$ \\
\hline & W (Weight) & & $372.5 \pm 309.5$ & $67.1-1333.4$ \\
\hline & Ov (Vertical Eye Diameter) & & $7.0 \pm 1.1$ & $4.4-9.3$ \\
\hline & Oh (Orizontal Eye Diameter) & & $7.5 \pm 1.2$ & $5.4-10.4$ \\
\hline & Lpf (Pectoral fin length) & & $27.0 \pm 7.4$ & $17.2-40.9$ \\
\hline
\end{tabular}

tuned so as the simulated catch under current fishing effort was equal to the reported catch in 2010 , i.e. 48 tons. Total harvest was rescaled to the suitable habitat so as to derive expected catches in $\mathrm{kg} / \mathrm{ha}$. Suitable habitat was estimated to be $20 \%$ of the total surface of the lake. This corresponds to the perimeter band from 0.5 to $12 \mathrm{~m}$, a zone that is considered suitable for eel on the basis of the characteristics of the bottom, available food sources and of the eel distribution and abundance as inferred by the fishermen. This approach is justified also by observations in other lentic systems (Fischer and Eckermann, 1997; Schulze et al., 2004; Yokouchi et al., 2009).

The demographic model was used to estimate fishery yields and silver eel production under different recruitment and management scenarios, namely: (a) "Current management" (fishing effort and stocking intensity in year 2012, i.e. 7.4 net-day and 848 ind/ha respectively); (b) "Pristine conditions" (i.e. no fishing and recruitment ten times higher than present stock intensity, i.e. 8480 ind/ha, so as to simulate the system at its carrying capacity); (c) a "Heavy exploitation" scenario (average fishing effort occurring in the '90s i.e. 99.8 net-day and current stocking intensity, i.e. $848 \mathrm{ind} / \mathrm{ha}$ ).

\section{RESULTS}

Samplings in the lake allowed characterizing the demographic structure of the Bolsena local stock (177 eels).

Yellow eels represented $60 \%$ of the catches, and silver eels $40 \%$. Size ranged between $250 \mathrm{~mm}$ and $920 \mathrm{~mm}$. Yellow eels had a mean body size of $459 \pm 114 \mathrm{~mm}$ and a mean weight of $210 \pm 201 \mathrm{~g}$, while silver eels had an average size of $548 \pm 150 \mathrm{~mm}$ and a mean weight $373 \pm 310 \mathrm{~g}$ (Table I).

Size frequency distributions (Figure 2) show $L$ ranging between $250-800 \mathrm{~mm}$ in yellow eel, $46 \%$ of individuals falling into the $400-450 \mathrm{~mm}$ class. Silver eels body sizes range between $350-920 \mathrm{~mm}$.

The population sex ratio, only considering sexually differentiated individuals, appeared displaced toward females (83\%). Gonad developmental stages were accurately described (Table II). Age estimated by otolith reading ranged from 3+ to 19+ years (Figure 3A). Modal age was $12+$ in females and $8+$ in males (Figure 3B).

The proportion of mature individuals ready to escapement as assessed by Pankhurst $\mathrm{OI}$ was $34 \%$.

Assessment of resident to migratory stages by Durif's Silvering Index yielded $58 \%$ of resident eels (Undifferentiated 38\%, 67 individuals, FII 20\%, 36 individuals), 18\% of potential migrant eels (FIII) and $24 \%$ of mature individuals (FIV and FV respectively $1 \%$ and $7 \%$; MII $15 \%$ ).

The mean annual growth for female eels was $47.68 \pm 12.42 \mathrm{~mm} \mathrm{yr}^{-1}$, while for male it was $45.38 \pm 12.69 \mathrm{~mm} \cdot \mathrm{yr}^{-1}$. The female growth parameters calculated from Bertalanffy equation 


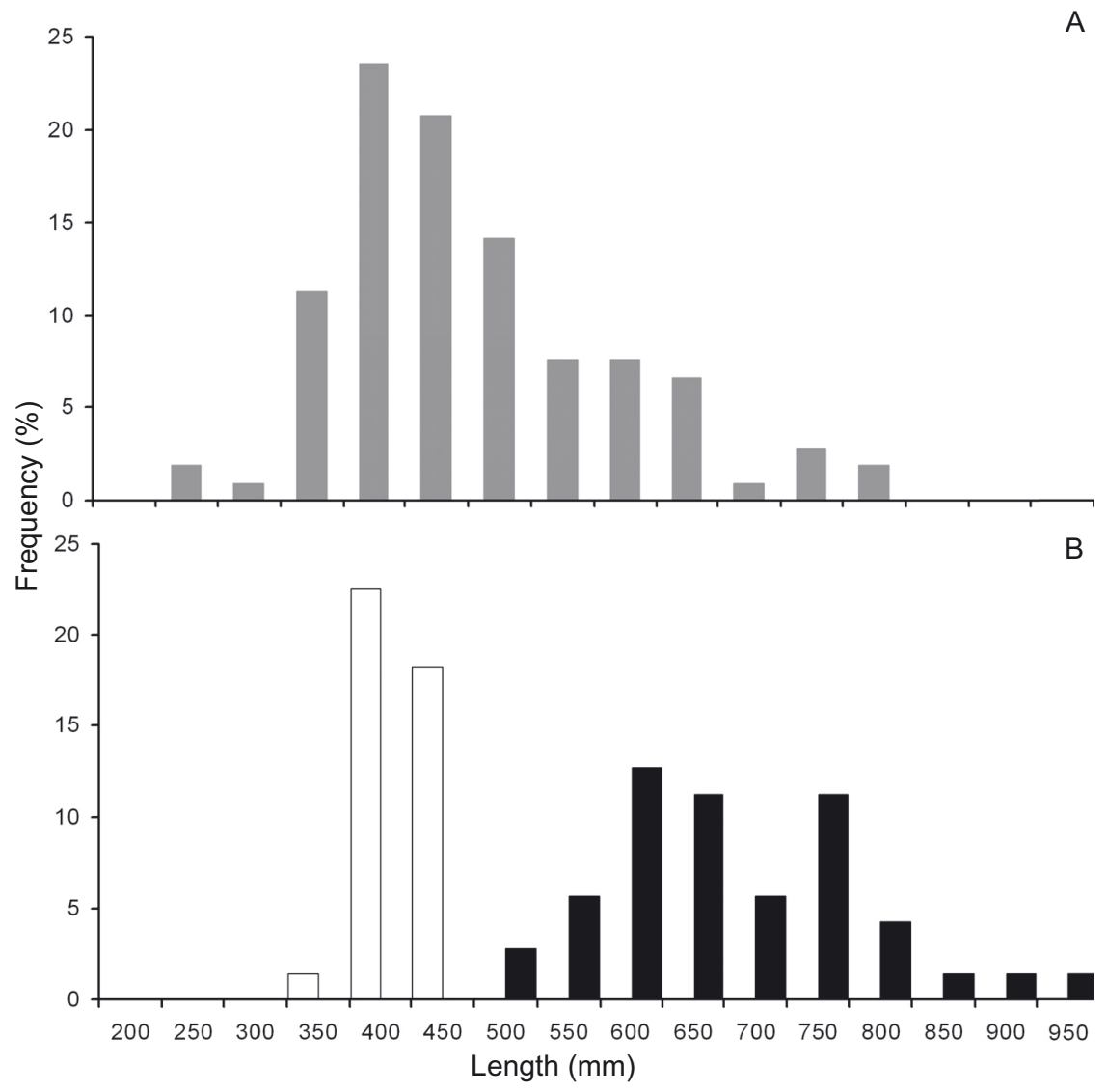

Figure 2

Length frequency distributions of yellow eels ( $A$, grey bars), and silver eels ( $B$, males: white bars and females: black bars) sampled at the Bolsena lake.

\section{Table II}

Number, mean total length, TL standard deviation and range, mean weight, w standard deviation and range, of eels at different gonad developmental stages.

\begin{tabular}{|l|c|c|c|c|c|}
\hline $\begin{array}{l}\text { Gonad developmental } \\
\text { stage }\end{array}$ & N & Mean $T L \pm$ SD $(\mathrm{mm})$ & Range & Mean \pm SD $(\mathrm{g})$ & Range \\
\hline Undifferentiated & 4 & $276.3 \pm 43.9$ & $245-340$ & $30.3 \pm 17.9$ & $19.6-57.1$ \\
\hline Mature male & 30 & $398.7 \pm 2.6$ & $345-445$ & $109.5 \pm 21.1$ & $67.1-147.0$ \\
\hline Immature female & 71 & $410.8 \pm 58.6$ & $305-570$ & $123.0 \pm 57.9$ & $52.0-301.3$ \\
\hline Early female & 23 & $550.1 \pm 123.1$ & $435-720$ & $333.7 \pm 132.8$ & $147.1-645.9$ \\
\hline Mature female & 49 & $662.8 \pm 97.8$ & $490-920$ & $590.0 \pm 281.6$ & $213.5-1333.4$ \\
\hline
\end{tabular}

were $L_{m}=952.98$ with a value of $k=0.08$. Estimated body growth trajectories are reported in Figure 4.

Catchability $q$ resulted to 0.012 net $^{-1} \cdot$ day $^{-2}$. Accordingly, 2012 yield was estimated to be $2.1 \mathrm{~kg} \cdot \mathrm{ha}^{-1}$.

Silver eel escapement from the lake (Table III) in pristine scenario was assessed as equal to $9.1 \mathrm{~kg} \cdot \mathrm{ha}^{-1}$. When considering the heavily exploited scenario, silver production was estimated to $0.17 \mathrm{~kg} \cdot \mathrm{ha}^{-1}$. Present escapement level is estimated at $5.3 \mathrm{~kg} \cdot \mathrm{ha}^{-1}$ and is sustained by the same level of stocking but allowing a much lower level of fishing exploitation. These values per hectare refer to eel production for the habitat suitable for eel on the basis of depth, and estimated in $20 \%$ of the total area of the lake, amounting therefore to 2280 ha. Pristine total biomass escaping the lake is hence estimated at $21 \mathrm{t}$ of silver eels, and actual level is $12 \mathrm{t}$. 


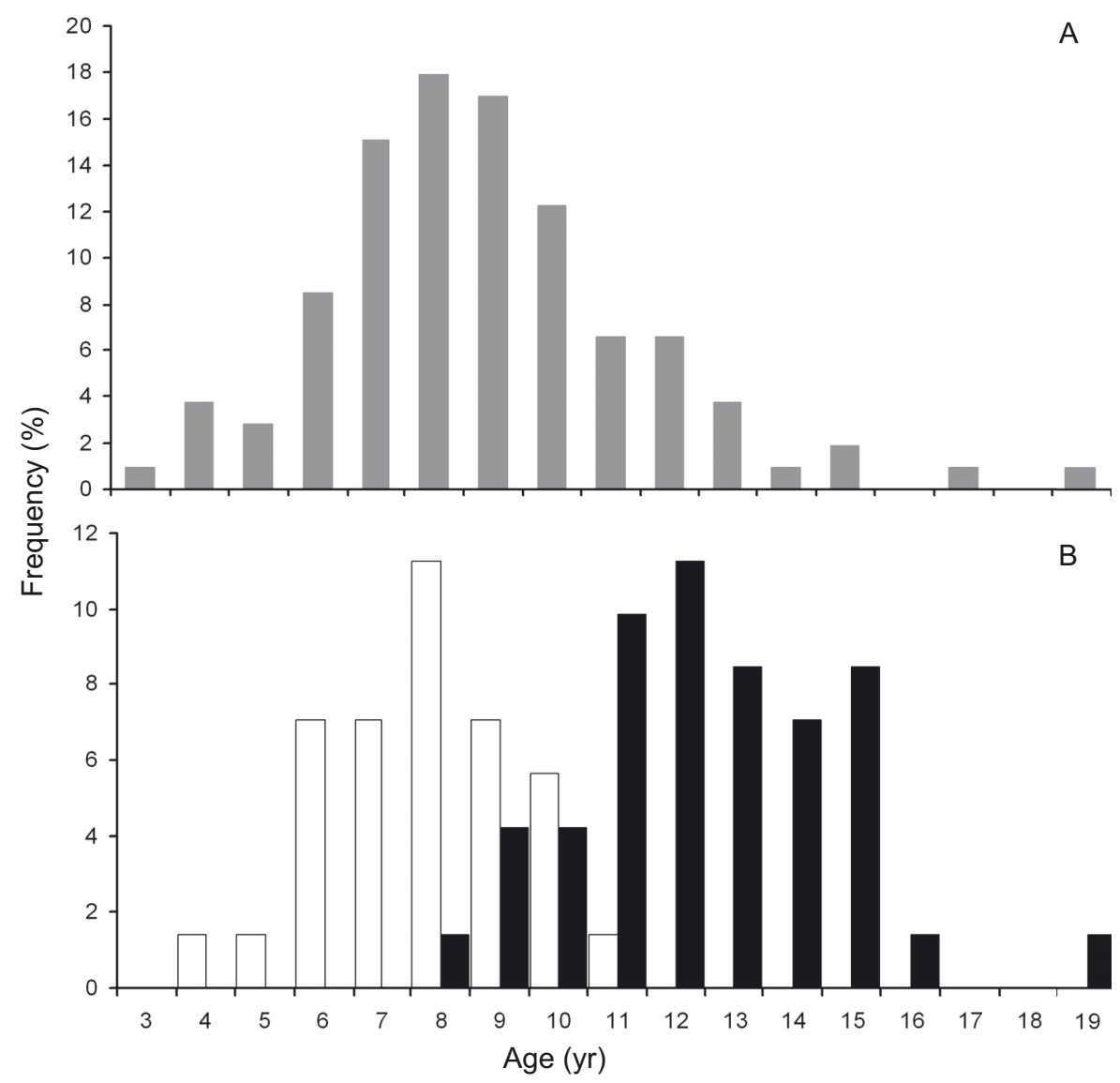

Figure 3

Age frequency distributions of yellow eels (A: grey bars) and silver eels (B: males white bars and females black bars) from the Bolsena lake.

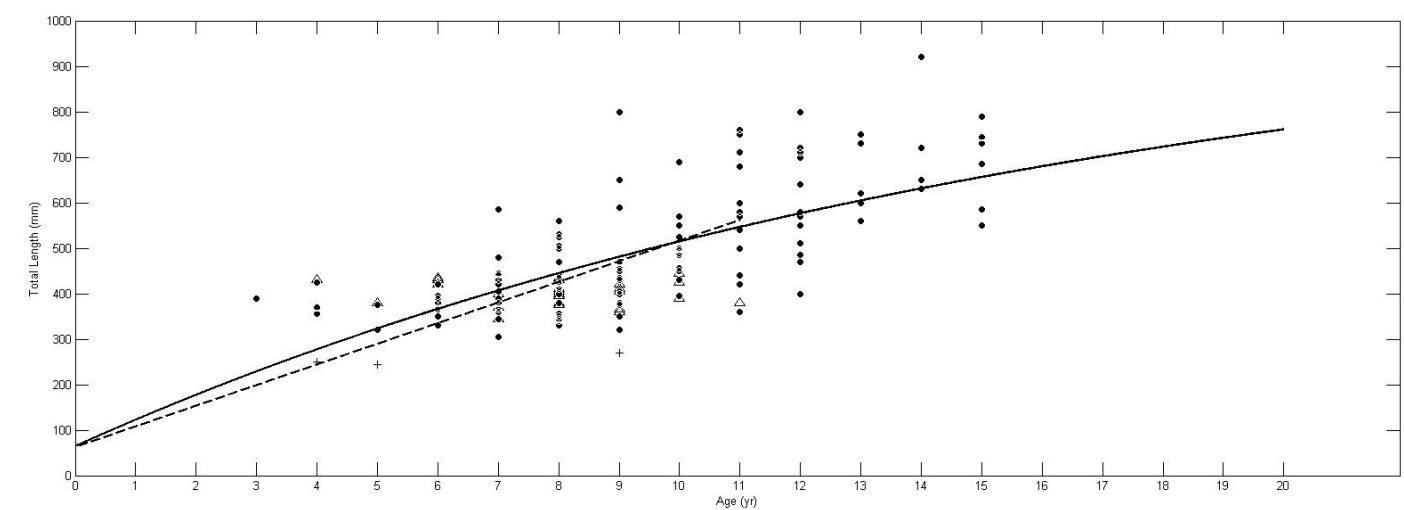

Figure 4

Theoretical growth curves of $A$. anguilla sample population from the Bolsena lake, female group and male group (dotted line).

\section{DISCUSSION}

\section{> DEMOGRAPHY OF THE BOLSENA LOCAL STOCK}

The Bolsena lake eel local stock exhibit demographic traits similar to those typically observed in other eel populations, such as bimodal length and age distributions of silver eels, and females are considerably larger and older than males (Tesch, 2003). Sex ratio is skewed towards 


\section{Table III}

Demographic simulations. Stocking density is a average on the restocking data series, lake area refers to suitable surface for eels (see text).

\begin{tabular}{|l|c|c|c|}
\hline $\begin{array}{l}\text { Stocking (ind/ha) of } \\
\text { glass eel or equivalent } \\
\text { (1 elver = 1/0.25 glass eel) }\end{array}$ & $\begin{array}{c}\text { Annual fishing effort } \\
\text { (fyke nets - days) }\end{array}$ & $\begin{array}{c}\text { Silver eel production } \\
\text { (escapement in kg/ha) }\end{array}$ & $\begin{array}{c}\text { Eel harvest } \\
\text { (kg/ha) }\end{array}$ \\
\hline $\begin{array}{l}\text { Pristine condition scenario: } \\
\text { no fishing exploitation } \\
\text { 8480 ind/ha }\end{array}$ & 0 & 9.1 & 0 \\
\hline $\begin{array}{l}\text { Heavy exploitation } \\
\text { scenario (1990's): } \\
\text { 848 ind/ha }\end{array}$ & 99.8 & 0.2 & 7.2 \\
\hline $\begin{array}{l}\text { Current management (2012): } \\
\text { 848 ind/ha }\end{array}$ & 7.4 & 5.3 & 2.1 \\
\hline
\end{tabular}

female eels; about $40 \%$ of the eels caught in the fyke nets have undergone the metamorphosis to the silver stage and can be considered as ready to migrate.

Female mean annual growth rate in length is similar to that of males (45.38 and $47.68 \mathrm{~mm} \cdot \mathrm{yr}^{-1}$ respectively). These growth parameters are higher than those found in northern and central Europe freshwater populations: Barrow River, N. Ireland: $33 \mathrm{~mm} \cdot \mathrm{yr}^{-1}$ (Moriarty, 1983); Burrishoole lakes (N. Ireland): $15 \mathrm{~mm} \cdot \mathrm{yr}^{-1}$ (Poole and Reynolds 1996b); Lough Neagh (N. Ireland): $26.50 \mathrm{~mm} \cdot \mathrm{yr}^{-1}$ (Rosell et al., 2005); River Havel system lakes: $45 \mathrm{~mm} \cdot \mathrm{yr}^{-1}$ (Simon, 2007); Jeziorak Lake (Poland): $41 \mathrm{~mm} \cdot \mathrm{yr}^{-1}$ (Nagiec and Bahnsawy, 1990). Yet, growth rates similar to those observed in Bolsena have been reported also in other Mediterranean populations such as Vaccarès Lagoon (France), $90 \mathrm{~mm} \cdot \mathrm{yr}^{-1}$ (Acou et al., 2003); Tiber River (Italy): $53.78 \mathrm{~mm} \cdot \mathrm{yr}^{-1}$ Fogliano Lagoon (Italy): $61.67 \mathrm{~mm} \cdot \mathrm{yr}^{-1}$; Lesina Lagoon (Italy): $88.30 \mathrm{~mm} \cdot \mathrm{yr}^{-1}$ (Capoccioni, 2012).

\section{$>$ EEL DEMOGRAPHY}

The estimated catchability is lower than what was estimated by a similar modelling approach (Bevacqua et al., unpublished) in a shallow Mediterranean lagoon habitats (ca $q=$ $0.1 \mathrm{net}^{-1} \cdot$ day $^{-2}$ in Camargue, southern France). This result is likely to reflect the higher probability for the gear to intercept eel in shallow waters, water depth in the Camargue lagoon being indeed remarkably lower, i.e. between 1-2 $\mathrm{m}$.

Annual fishing mortality rate for yellow eels large enough to be captured by fyke nets with a $16 \mathrm{~mm}$ mesh size (see Bevacqua et al., 2009b for details) was estimated to range from $0.09 \mathrm{yr}^{-1}$ under current management to $1.2 \mathrm{yr}^{-1}$ in the "heavy exploitation" scenario. The overall low fishing mortality is hence due to a combination of low catchability and low fishing effort, at least under current management.

Simulation results, particularly those relevant to the estimation of stock abundance and spawning escapement under pristine conditions are strongly affected by the choice of the parameter $k$ in the density-dependent survival function from glass eel to the elver stages (Appendix A) as this parameter ultimately determines the carrying capacity of the system. In fact the maximum number of yellow eels that can annually settle as 1-yr old eels is equal to $k$. In the present work we assumed $k=225$ ind/ha on the basis of similar studies performed on a intensively monitored and studied system, i.e. the Camargue lagoons (Bevacqua et al., 2007). Ideally, such parameter should be assessed by dedicated studies.

\section{> ESCAPEMENT ESTIMATES AND CHANGES IN MANAGEMENT}

Silver eel production under current glass eel stocking level is estimated in $12 \mathrm{t}$, i.e. almost $60 \%$ of the estimated pristine level. Therefore, the target of $40 \%$ of the pristine escapement 
from this single catchment as indicated by the management framework established by the CE Regulation 1100/2007 would be attained; if i) the effective escapement from the lake and the downstream migration were ensured; ii) glass eel stocking were maintained under present intensity, i.e. about 800 ind/ha; and (iii) fishing effort were kept moderate at present levels. Our simulations show also the historic management, i.e. the fishing pressure exerted in the ' $90 \mathrm{~s}$, clearly overexploited the silver eel stock by leaving a mere $400 \mathrm{~kg}$ of silver eel escapement. i.e. less than $2 \%$ of the potential spawning stock under pristine conditions. This would not only dramatically reduce the number of spawner able to migrate to the sea but would probably also select mainly for slow somatic growth, as recently pointed out by Bevacqua et al. (2012).

The recovery of silver eel production and hence of the potential escapement from the lake seems mainly due to the decline of fishing intensity and to the support to recruitment provided by glass eel stocking. The reduction of fishing mortality is related to on-going socio-economic processes, such as a shift in fishing effort towards other more lucrative target species, reduced interest of the market towards eel and fishers ageing. This is a feature common to several small scale eel fisheries, such as the one operating in the Lough Neagh (Rosell et al., 2005), one of the largest fisheries in Europe. In this scenario stocking, albeit still practiced to sustain the local eel stock and related fishery, plays a different role, sustaining silver eel production and escapement, with important implication for eel conservation.

\section{>RESTORATION OF RIVER CONNECTIVITY}

Assessment of the efficiency of the restoration interventions with specific reference to eel remains crucial for planning a sustainable management of the Marta-Bolsena system and of the eel local stock. Sporadic catch of eel during electro-fishing points to an improved chance for colonization, impossible up to 2007, as attested by recent campaigns (AGEI, 2008; Andreani et al., 2010). Thus, recruits to the river Marta mouth have now enhanced probabilities to colonize the upper stretch of the river and its tributaries. On the other hand, escapement from the lake strictly depends on the management of the sluice gate connecting the lake to the river, and this compromises effective escapement to the sea.

\section{> IMPLICATIONS FOR MANAGEMENT}

The importance of re-establishing or maintaining river continuum and longitudinal connectivity in rivers for fish conservation has been repeatedly stressed (Cowx, 2002) and even more specifically for eel (Laffaille et al., 2005). In the Bolsena-Marta system, this appears fundamental for allowing colonization of ascending elvers from the river mouth and the low river stretch, but even more because this will enable escapement of the silver eel biomass already present in the lake.

The paradox is that in the absence, or because of delays, of such restoration actions, the continuation of silver eel harvest, maintaining the current level of fishing effort, is even desirable, as long as a "return quota" is envisaged, and actuated by releasing breeders downstream of the dams and the natural waterfall.

The present experience highlights the fact that individual actions, such as reduction of fishing mortality, sustaining local fisheries by stocking, or habitat restoration plans even implying relevant efforts and technologies, could fail to provide significant contributions to the restoration of the stock if they are not integrated into a management scheme. Moreover, the relative roles of individual actions have to be tailored to the local situation. Under these circumstances, simulation models assume a key role in assessing different scenarios, reconstructing baselines and reference points, such as the spawner escapement under pristine conditions or alternative management plans. The estimation of actual escapement is obviously crucial as well (Bilotta et al., 2011): when it cannot be estimated through direct counts based, markrecapture experiments or tagging and telemetry, simulation models are a very powerful tool to assess compliance of management measure to the EU regulation targets. 


\section{CONCLUSIONS}

A most general issue is whether the Bolsena-Marta system can be considered as a key site for eel conservation, and whether this habitat typology can provide a contribution to the global conservation of eel stock. Productivity, as demonstrated by eel production and eel growth in the Bolsena lake, is good, if management practices finalised to sustain local eel stocks are pursued, and will bring about a definite effect if escapement routes are guaranteed. Thus, the maintenance of traditional enhanced fisheries is a specific tool allowing a contribution to overall eel escapement at the regional scale (Ciccotti, 2005). With regards to fishery management, recent analyses show that cases exist where the conservation target can be achieved without further reductions in harvest (Bevacqua et al., 2007), and this is the case of the Bolsena and Marta eel fisheries, that have decreased spontaneously to a level compatible also for eel conservation targets. Conflicts that are likely to arise between fishers and policy makers could be further reduced if the interests of fishers are explicitly accounted (Bevacqua et al, 2009a), or if they are involved directly in the management process.

Finally, an integrated approach to management must be addressed at the catchment scale, as evidenced by Collares-Pereira and Cowx (2004), when freshwater fish conservation is dealt with. This appears to be true also when referred to the conservation of the European eel, a species for which local scale actions shall hopefully contribute to conservation at global scale.

\section{ACKNOWLEDGEMENTS}

The authors wish to thank Paolo Andreani of Assessorato Ambiente of the Province of Viterbo, responsible of the implementation of the interventions on the river Marta, and the Ufficio Pesca of the Province of Viterbo, that has provided data on fisheries and restocking actions. The authors are grateful to the Bolsena and the Marta fishers, for help in samplings and for sharing fishery data.

\section{APPENDIX A: DEMOGRAPHIC MODEL}

Individuals are structured in classes according to life stage and sex. Any class $i$ is identified by an Acronym where the first letter denotes the life stage (i.e. G, $Y, S$ for Glass/Yellow/Silver) and the second one the sex (i.e. $M, F$ for Male/Female). Variable $n_{i}(x, t)$ indicates the abundance of eels of age $x$, at time $t$, in class $i$. The model was run with constant recruitment and fishing effort until equilibrium was reached.

\section{> GLASS EEL RECRUITMENT}

The number of glass eel $G$ entering the system was computed from data on stock recruitment, considering that one individual on average weights $0.3 \mathrm{~g}$. In the case of elvers stocking the weight was assumed to be $70 \mathrm{~g}$. Mean survival from glass eels to the elver stage was assumed to be equal to 0.25 according to Dekker (2003).

Then, the number of stocked eels surviving acclimation to the new environment and successfully settling was computed as:

$$
\begin{aligned}
& n_{y m}(x, t)+n_{y f}(x, t)=f_{r m} \sigma_{E} n_{E}(x, t) \\
& n_{y f}(x, t)=\left(1-f_{r m}\right) \sigma_{E} n_{E}(x, t)
\end{aligned}
$$

where $n_{E}$ is the number of elvers, $f_{r m}$ is the fraction of males in a cohort and $\sigma_{E}$ the survival fraction of glass eel. $\sigma_{E}$ was assumed to be a density-dependent function according to Bevacqua et al. (2007), namely:

$$
\sigma_{E}=\frac{k}{k+n_{E}}
$$


where $k$ is the carrying capacity for annual settlement of new eels in the system. $k$ was estimated to be equal to $450 \mathrm{ind} / \mathrm{ha}$ in the brackish water Camargue lagoon (Bevacqua et al., unpublished) and was assumed halved in Bolsena lake, as freshwater systems are known to be less productive that brackish system. Fraction of males $f_{r m}$ was set $=1 / 3$ and for females $=$ $2 / 3$ so as to represent the skewed sex ratio.

\section{>POPULATION DYNAMICS}

The population dynamics during the continental phase are described by the following recursive equations:

$$
\begin{aligned}
n_{Y M}(x+1, t+1) & =\sigma_{Y M}\left[1-\gamma_{Y M}(x)\right] n_{Y M}(x, t) \\
n_{Y F}(x+1, t+1) & =\sigma_{Y F}\left[1-\gamma_{Y F}(x)\right] n_{Y F}(x, t) \\
n_{S M}(x+1, t+1) & =\sigma_{Y M} \gamma_{Y M}(x) n_{Y M}(x, t) \\
n_{S F}(x+1, t+1) & =\sigma_{Y F} \gamma_{Y F}(x) n_{Y F}(x, t) .
\end{aligned}
$$

Where $\sigma_{i}$ is annual survival and $\gamma_{i}$ is the fraction of yellow eels metamorphosing to the silver stage. Values and meaning of all the parameters included in these equations are further discussed in the following sections.

Eel survival. Natural $(\mathrm{M})$ and fishing $(\mathrm{F})$ mortality rates were computed respectively as $M=$ $0.14 \mathrm{yr}^{-1}$ (Dekker, 2000) and $F=q E \Phi$ for yellow eels and $F=2 q E \Phi$ for silver eels where $q$ is a catchability parameter (to be estimated), $E$ is the annual fishing effort as total number of nets installed in the year (net day) ${ }^{(\text {n.nets.n.fishing day }}$ ) (Bevacqua et al., 2009).

Silver eels are then subject to a fishing mortality rate equal to $F_{S}=2 F$, which reflects the fact that silver eels have higher probability to be fished, before being considered as "escaping silver eels" constituting the spawning stock.

Selectivity $\Phi$ of the fishing gear was estimated following Bevacqua et al., 2009 by considering a stretched mesh size of $16 \mathrm{~mm}$.

Probability of surviving fishing and natural mortality was hence computed as:

$$
\sigma_{Y}=e^{(-(M+F))}
$$

Body growth.

The mean annual growth increments $G$ of sampled eels was computed as:

$$
G=\frac{L_{c}-L_{0}}{t}
$$

where $L_{c}$ is the fish length at capture, $L_{0}$ is the mean glass eel length $(63 \mathrm{~mm})$ and $t$ is the continental age estimated by counting the rings after the glass eel mark.

Body growth trajectory of females eels were estimated through the von Bertalanffy (1957) growth curve:

$$
L(t)=L_{0}-\left(L_{\infty} L_{0}\right) e^{-k t}
$$

where $L$ is total length at time $t, L_{\infty}$ is the asymptotic length, $K$ the rate at which asymptotic length is approached $L_{\infty}$. As data on males included only silver individuals that concluded the growing phase, we could not assess a von Bertalanffy growth curve for the males and opted for a constant body growth i.e.

$$
L(t)=L_{0}+G \cdot t
$$

Sexual maturation. Maturation rates $\gamma_{i}(x)$ represent the fraction of individuals that undergo sexual maturation at age $x$.

Maturation rates are sex- and size-dependent and were estimated as in Bevacqua et al. (2006):

$$
\gamma_{i j}=\gamma_{\operatorname{MAX}} / \mathrm{e}^{\left(\lambda_{l}-L(x)\right) \eta_{i}^{-1}}
$$


where $L_{i}(x)$ is body length, $\gamma_{M A X}$ the maximum rate of maturation, $\lambda_{i}$ a semi-saturation constant and $\eta_{i}$ is a parameter inversely proportional to the slope of the metamorphosis curve at $L_{i}(x)=\lambda_{i}$.

The values of $\gamma_{\operatorname{MAX}} \lambda_{i}$ and $\eta_{i}$ are taken from Bevacqua et al. (2006).

\section{REFERENCES}

Acou A., Lefebvre F., Contournet P., Poizat G., Panfili J. and Crivelli A.J., 2003. Silvering of female eels (Anguilla anguilla) in two sub-populations of the Rhône delta. Bull. Fr. Pêche Piscic., 368, 55-68.

Acou A., Boury P., Laffaille P., Crivelli A.J., Feunteun E., 2005. Towards a standardized characterization of the potentially migrating silver European eel (Anguilla anguilla L.). Arch. Hydrobiol., 164, 237-255.

AGEI, 2008. Interventi di ripristino della continuità fluviale del Fiume Marta. Tecnical Report, AGEI, Provincia di Viterbo, ICR Mare.

Allan J.D., 2004. Landscapes and riverscapes: the influence of land use on stream ecosystems. Annu. Rev. Ecol. Syst., 35, 257-284.

Als T.D., Hansen M.M., Maes G.E., Castonguay M., Riemann IL., Aarestrup K., Munk P., Sparholt H., Hanel R. and Bernatchez L. 2011. All roads lead to home: panmixia of European eel in the Sargasso Sea. Mol. Ecol., 20, 1333-1346.

Andreani P., D’Ambra R., Fusari A., Rampacci M. and Tancioni L., 2010. Passaggi per pesci sull'asta principale del Fiume Marta (VT) - Osservazioni preliminari sui popolamenti ittici e sulle popolazioni potenzialmente migranti. Book of abstracts - XX Congresso S.It.E., Roma, 27-30 Settembre 2010: 166.

ARSIAL, 2009. Definizione di un piano di gestione delle risorse ittiche nel lago di Bolsena. Final report.

Barbanti L., Bonomi G., Carollo A., Chiaudani G., Ferrari I., Gerletti M., Nocentini A. M., Ruggiu D. and Tonolli L., 1971. Limnologia ed ecologia dei laghi di Bolsena, Bracciano e Vico. Istituto Italiano di Idrobiologia - CNR Pallanza, 263 pp.

Bevacqua D., Melia P., Crivelli A., De Leo G.A., and Gatto M., 2006. Timing and rate of sexual maturation of European eel in brackish and freshwater environments. J. Fish Biol., 69, 200-208.

Bevacqua D., Melia P., Crivelli A.J., Gatto M. and De Leo G.A., 2007. Multi-objective assessment of conservation measures for the European eel (Anguilla Anguilla): an application to the Camargue lagoons. ICES J. Mar. Sci., 64, 1483-1490.

Bevacqua D., Melià P., Crivelli A.J., Gatto M. and De Leo G.A., 2009a. Assessing management plans for the recovery of the European eel: A need for multi-objective analyses. Am. Fish. Soc. Symp., 69, $637-647$.

Bevacqua D., De Leo G.A., Gatto M. and Melia P., 2009b. Size selectivity of fyke nets for European eel Anguilla anguilla. J. Fish Biol., 74, 2178-2186.

Bevacqua D., Melià P, De Leo G. A. and Gatto M., 2011. Intraspecific scaling of natural mortality in fish: the paradigmatic case of the European eel. Oecologia, 165, 333-339.

Bevacqua D., Capoccioni F., Melià P., Vincenzi S., Pujolar J.M., De Leo G.A. and Ciccotti E., 2012. Fishery-induced selection for slow somatic growth in European eel. PLoS ONE 7, e37622.

Bilotta G.S., Sibley P., Hateley J. and Don A., 2011. The decline of the European eel Anguilla anguilla: quantifying and managing escapement to support conservation. J. Fish Biol., 78, 23-38.

Capoccioni F., 2012. Biological features of eel (Anguilla anguilla, L. 1758) local stocks in the Mediterranean area, as a function of different ecological conditions. Ph.D. Thesis. Dipartimento di Biologia, Università degli Studi di Roma Tor Vergata.

Ciccotti E., 2005. Interactions between capture fisheries and aquaculture: the case of the eel (Anguilla anguilla L., 1758). In: Cataudella S., Massa F. D. Crosetti (eds.), Interactions between capture fisheries and aquaculture: a methodological perspective, Studies and Reviews. GFCM, 78, 190-203.

Collares-Pereira M.J. and Cowx I.J., 2004. The role of catchment scale environmental management in freshwater fish conservation. Fish. Manage. Ecol., 11, 302-312.

Colombo G. and Grandi G., 1996. Histological study of the development and sex differentiation of the gonad in the European eel. J. Fish Biol., 48, 493-512.

Council Regulation (EC) No. 1100/2007 of 18 September 2007 establishing measures for the recovery of the stock of European eel. OJC, L 248, 17-23. 
Cowx I.G., 2002. Analysis of threats to freshwater fish conservation: past and present challenges. In: M.J. Collares-Pereira; I.G. Cowx; M.M. Coelho, Conservation of Freshwater Fishes: Options for the future. Blackwell Science, Oxford, UK, 201-220.

Cowx I.G. and Welcomme R.L., 1998. Rehabilitation of rivers for fish. FAO, Fishing News Books. Blackwell Science Ltd., Oxford and Northampton.

Dannewitz J., Maes G.E., Johansson L., Wickström H., Volckaert F.A.M. and Jarvi T., 2005. Panmixia in the European eel: a matter of time. Proc. R. Soc. B., 272, 1129-1137.

Dekker W., 2000a. A Procrustean assessment of the European eel stock. ICES J. Mar. Sci., 57, 938-947.

Dekker W., 2000b. The fractal geometry of the European eel stock. ICES J. Mar. Sci., 57, 109-121.

Dekker W., 2003. Did lack of spawners cause the collapse of the European eel, Anguilla anguilla? Fish. Manage. Ecol., 10, 365-376.

Dekker W., 2008. Coming to grips with the eel stock slip-sliding away. International Governance of Fisheries Ecosystems: Learning from the Past, Finding Solutions for the Future. Am. Fish. Soc. Symp., 62, 335-355.

Dekker W., 2009. A conceptual management framework for the restoration of the declining European eel stock, in: Casselman J.M. et al. 2009. Eels at the edge: science, status, and conservation concerns. Am. Fish. Soc. Symp., 58, 3-19.

Durif C., Dufour S. and Elie P., 2005. The silvering process of Anguilla anguilla: a new classification from the yellow resident to the silver migration stage. J. Fish Biol. , 66, 1025-1043.

Fantucci R., 2007. Dendrogeomorphological analysis of shore erosion along Bolsena lake (Central Italy). Dendrochronologia, 24, 69-78.

Feunteun E., 2002. Management and restoration of European eel population (Anguilla anguilla): an impossible bargain. Ecol. Eng., 18, 575-591.

Fischer P. and Eckmann R., 1997. Spatial distribution of littoral fish species in a large European lake, Lake Constance, Germany. Arch. Hydrobiol., 140, 91-116.

Hadwen W.L., Arthington A.H. and Mosisch T.D., 2003. Impact of tourism on dune lakes on Fraser Island, Australia. Lakes Reservoirs: Res. Manage., 8, 15-26.

ICES 2004. International Council for the Exploration of the Sea. Report of the ICES/EIFAC Working Group on Eels. ICES C.M. 2004/ACFM: 09.

ICES 2005. International Council for the Exploration of the Sea. Report of the ICES/EIFAC Working Group on Eels. ICES C.M. 2005/ACFM: 01.

ICES 2007. International Council for the Exploration of the Sea. Report of the ICES/EIFAC Working Group on Eels. ICES C.M. 2007/ACFM: 23.

ICES 2009. Annex 4: manual for the ageing of Atlantic eel. In ICES Workshop on Age Reading of European and American Eel (WKAREA), 20-24 April 2009, Bordeaux, France. ICES C.M. 2009:ACOM: 48.

IUCN, 2010. The 2010 Red List of threatened species.

Laffaille P., Acou A., Guillouët J. and Legault A., 2005. Temporal changes in European eel, Anguilla anguilla, stocks in a small catchment after installation of fish passes. Fish. Manage. Ecol., 12, $123-129$.

Lin Y.J. and Tzeng, W.N. 2009. Validation of annulus in otolith and estimation of growth rate for Japanese eel Anguilla japonica in tropical southern Taiwan. Environ. Biol. Fishes, 84, 79-87.

Maitland P.S., 1995. The conservation of freshwater fish: past and present experience. Biol. Conserv., 72, 259-270.

Melia P., Bevacqua D., Crivelli A. J., Panfili J., De Leo G.A and Gatto M., 2006a. Sex differentiation of the European eel in brackish and freshwater environments: a comparative analysis. J. Fish Biol., $69,1228-1235$.

Melia P., Bevacqua D., Crivelli A., De Leo G.A., Panfili J. and Gatto M., 2006b. Age and growth of Anguilla anguilla in the Camargue lagoons. J. Fish Biol., 68, 876-890.

Moriarty C., 1983. Age determination and growth rate of eels, Anguilla anguilla (L.). J. Fish Biol., 23, 257-264.

Moriarty C. and Dekker W., 1997. In Dekker W., 2003. Did lack of spawners cause the collapse of the European eel, Anguilla anguilla? Fish. Manage. Ecol., 10, 365-376. 
Nagiec M. and Bahnsawy M.H., 1990. Age and growth of female eels, Anguilla anguilla L., in a Polish lake, Jeziorak Lake, Mazurian Lake District, Poland. Aquacult. Fish. Manage., 21, 459-470.

Orban E., Di Lena G., Nevigato T., Casini I., Caproni R., Santaroni G. and Giulini G., 2007. Nutritional quality and safety of European perch (Perca fluviatilis) from three lakes of Central Italy. Food Chem., $100,482-490$.

Pankhurst N.W., 1982. Relation of visual changes to the onset of sexual maturation in the European eel Anguilla anguilla (L.). J. Fish Biol., 21, 127-140.

Poff N.L., Angermeier P.L., Cooper S.D., Lake P.S., Fausch K.D., Winemiller K.O., Mertes L.A.K., Oswood M.W., Reynolds J. and Rahel F.J., 2001. Fish diversity in streams and rivers. In: Stuart Chapin III; O.E. Sala and E. Huber-Sannwald. Global biodiversity in a changing environment: scenarios for the 21st century. Springer-Verlag, New York, USA.

Poole W.R. and Reynolds J.D., 1996b. Growth rate and age at migration of Anguilla anguilla. J. Fish Biol., 48, 633-642.

Poole W.R., Reynolds J.D. and Moriarty C., 2004. Early post-larval growth and otolith patterns in the eel Anguilla Anguilla. Fish. Res., 66, 107-114.

Pujolar J.M., De Leo G.A., Ciccotti E., and Zane L. 2009. Genetic composition of Atlantic and Mediterranean recruits of European eel Anguilla anguilla based on EST-linked microsatellite loci. J. Fish Biol., 74, 2034-46.

Pujolar J.M., Marino I.A., Milan M., Coppe A., Maes G.E., Capoccioni F., Ciccotti E., Bervoets L., Covaci A., Belpaire C., Cramb G., Patarnello T., Bargelloni L., Bortoluzzi S. and Zane L., 2012. Surviving in a toxic world: transcriptomics and gene expression profiling in response to environmental pollution in the critically endangered European eel. BMC genomics, 13, 507.

Ringuet S., Muto F. and Raymakers C., 2002. Eels: their harvest and trade in Europe and Asia. Traffic Bulletin 19, 80-106.

Rosell R., Evans, D. and Allen, M., 2005. The eel fishery in Lough Neagh, Northern Ireland - an example of sustainable management? Fish. Manage. Ecol., 12, 377-385.

Simon J., 2007. Age, growth, and condition of European eel (Anguilla anguilla) from six lakes in the River Havel system (Germany). ICES J. Mar. Sci., 1414-1422.

Schulze T., Kahl U., Radke R. J. and Benndorf J., 2004. Consumption, abundance and habitat use of Anguilla anguilla in a mesotrophic reservoir. J. Fish Biol., 65, 1543-1562.

Tancioni L., Scardi M. and Cataudella S., 2006. Riverine fish assemblages in temperate rivers. Biological Monitoring of Rivers: Applications and Perspectives. G. Ziglio; M. Siligardi; G. Flaim. Wiley, London, UK., 47-70.

Tesch F.W., 2003. The Eel. Blackwell Science, Oxford, UK.

Thillart G. van den, Dufour S. and Rankin J.C., 2009. Spawning Migration of the European Eel. Fish Fisheries Serie., 30, 13-38.

von Bertalanffy L. 1957. Quantitative laws in metabolism and growth. Q. Rev. Biol., 32, 217-231.

Yokouchi K., Aoyama J., Miller M.J., McCarthy T.K., and Tsukamoto K., 2009. Depth distribution and biological characteristics of the European eel Anguilla anguilla in Lough Ennell, Ireland. J. Fish Biol., 74, 857-71. 